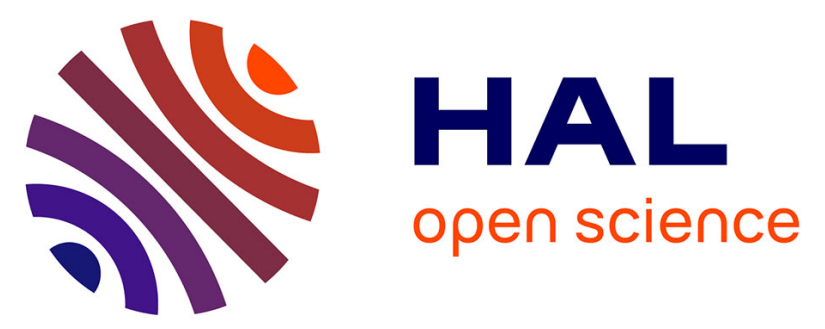

\title{
SGLT-2 inhibitors and GLP-1 receptor agonists for nephroprotection and cardioprotection in patients with diabetes mellitus and chronic kidney disease. A consensus statement by the EURECA-m and the DIABESITY working groups of the ERA-EDTA
}

P. Sarafidis, C. J. Ferro, E. Morales, A. Ortiz, J. Malyszko, R. Hojs, K. Khazim, R. Ekart, J. Valdivielso, D. Fouque, et al.

\section{- To cite this version:}

P. Sarafidis, C. J. Ferro, E. Morales, A. Ortiz, J. Malyszko, et al.. SGLT-2 inhibitors and GLP-1 receptor agonists for nephroprotection and cardioprotection in patients with diabetes mellitus and chronic kidney disease. A consensus statement by the EURECA-m and the DIABESITY working groups of the ERA-EDTA. Nephrology Dialysis Transplantation, 2020, 35 (10), pp.1825. 10.1093/ndt/gfz137 . inserm-03261177

\section{HAL Id: inserm-03261177 https://www.hal.inserm.fr/inserm-03261177}

Submitted on 15 Jun 2021

HAL is a multi-disciplinary open access archive for the deposit and dissemination of scientific research documents, whether they are published or not. The documents may come from teaching and research institutions in France or abroad, or from public or private research centers.
L'archive ouverte pluridisciplinaire HAL, est destinée au dépôt et à la diffusion de documents scientifiques de niveau recherche, publiés ou non, émanant des établissements d'enseignement et de recherche français ou étrangers, des laboratoires publics ou privés.

\section{(c) (1) $\$$}

Distributed under a Creative Commons Attribution - NonCommerciall 4.0 International 
Pantelis Sarafidis, Charles J. Ferro, Enrique Morales, Alberto Ortiz, Jolanta Malyszko,

Radovan Hojs, Khaled Khazim, Robert Ekart, Jose Valdivielso, Denis Fouque, Gérard M. London,

Ziad Massy, Petro Ruggenenti, Esteban Porrini, Andrzej Wiecek, Carmine Zoccali,

Francesca Mallamaci and Mads Hornum

SGLT-2 inhibitors and GLP-1 receptor agonists for nephroprotection and cardioprotection in patients with diabetes mellitus and chronic kidney disease. A consensus statement by the EURECA-m and the DIABESITY working groups of the ERA-EDTA, Nephrology Dialysis Transplantation 2019; gfy407. doi: 10.1093/ndt/gfy407

In the original article, the words 'micro- or microalbuminuria' should have read 'micro- or macroalbuminuria' in the top boxes of Figures 4 and 5.

doi: $10.1093 / \mathrm{ndt} / \mathrm{gfz} 137$

Advance Access publication 9 August 2019 